\title{
PEMBERDAYAAN KELOMPOK SADAR WISATA (POK-DARWIS) SEBAGAI PENGGERAK KEMAJUAN WISATA EDUKASI JUMIANG
}

\author{
Campina Illa Prihantini ${ }^{1)}$, Lutfiyanto ${ }^{2)}$, Musoffan $^{3)}$, dan Darwis ${ }^{4)}$ \\ ${ }^{1}$ Universitas Sembilan belas November, Kolaka, Indonesia \\ 2,3,4) STIE Bakti Bangsa Pamekasan, Jawa Timur. Indonesia. \\ 1) campinailla26@gmail.com
}

\begin{abstract}
Tourism today has become a primary need for some people. The high demand for tourism is a challenge for the management of a tourist place. Even so in the tourist area of Jumiang. The need for a study and at the same time service in the tourist area of Jumiang is a breath of fresh air in the development of the tourist area of Jumiang. This dedication activity was the result of collaboration between the Beginning Lecturer Research Team (PDP) and the Tematic KKN Bakti Bangsa Pamekasan College of Economics program team. The Tematic KKN Program of STIE Bakti Bangsa Pamekasan was able to have a real impact on the changing conditions of the tourist area of Jumiang. Various Community Service Programs have been offered to tour operators and have been successfully carried out. By utilizing the opportunities and available resources, this service activity turned out to be received enthusiastically by various parties, both managers and visitors.
\end{abstract}

Keywords: Empowerment, Pok-Darwis, Educational Tourism

\begin{abstract}
Abstrak.Pariwisata saat ini telah menjadi kebutuhan primer bagi sebagian orang. Tingginya permintaan pariwisata menjadi tantangan tersendiri bagi pihak pengelola sebuah tempat wisata. Pun demikian di kawasan wisata Jumiang. Perlunya sebuah penelitian dan sekaligus pengabdian di kawasan wisata Jumiang menjadi angin segar dalam pengembangan kawasan wisata Jumiang. Kegiatan pengabdian ini merupakan hasil kolaborasi Tim Peneliti Penelitian Dosen Pemula (PDP) dengan tim program Kuliah Kerja Nyata (KKN) Tematik Sekolah Tinggi Ilmu Ekonomi (STIE) Bakti Bangsa Pamekasan. Program KKN Tematik STIE Bakti Bangsa Pamekasan ternyata mampu memberikan dampak yang nyata terhadap perubahan kondisi kawasan wisata Jumiang. Berbagai program KKN telah ditawarkan kepada pihak pengelola wisata dan telah berhasil dilakukan. Dengan memanfaatkan kesempatan dan sumberdaya yang tersedia, kegiatan pengabdian ini ternyata dapat diterima dengan antusias oleh berbagai pihak, baik pengelola, maupun pengunjung.
\end{abstract}

Kata Kunci: Pemberdayaan, Pok-Darwis, Wisata Edukasi

\section{PENDAHULUAN}

Kabupaten Pamekasan hanya memiliki beberapa objek wisata unggulan, misalnya Pantai Jumiang, Pantai Talang Siring, Kawasan Wisata Batik, Museum Ronggosukowati, dan Wisata Religi Batu Ampar (BPS 2018). Beberapa waktu terakhir, objek wisata di Kabupaten Pamekasan bertambah, misalnya Wisata Selamat Pagi Madura, Brukoh Hills, dan beberapa objek wisata kuliner. Melihat potensi yang dimiliki oleh Kabupaten Pamekasa, sebenarnya banyak hal yang dapat dilakukan dalam pengembangan kawasan wisata yang telah lama berdiri. Misalkan perbaikan sarana dan prasarana wisata, promosi melalui media sosial, dan segala hal yang bersifat lebih kekinian. Promosi melalui media sosial merupakan langkah yang sngat efektif dalam melakukan pengembangan suatu wisata (Asri et al. 2018). Bakti et al. (2018) 
menunjukkan bahwa pelatihan komunikasi pariwisata melalui media sosial ternyata berdampak positif terhadap peningkatan jumlah kunjungan di Pantai Sayang Keualang, Kabupaten Garut.

Seiring dengan meningkatnya jumlah penduduk dan wisatawan yang datang berkunjung ke Pulau Madura, terjadi peningkatan permintaan wisata sebagai kebutuhan sekunder. Bahkan saat ini, berwisata atau rekreasi telah berubah sifatnya menjadi kebutuhan primer, terlebih bagi masyarakat milineal (Umam 2015). Berbagai alasan menjadi motivasi para wisatawan ketika melakukan kegiatan wisata (Yoeti, 2010). Misalnya, (1) keinginan untuk menghilangkan kejenuhan dan kepenatan setelah melakukan aktifitas sehari-hari yang melelahkan di perkotaan, (2) sebagai media untuk beristirahat sejenak dari tuntutan kerja, dan (3) merupakan bagian dari gaya hidup yang dianut oleh masyarakat perkotaan.

Kegiatan pengabdian ini bertujuan untuk menyambut tingginya permintaan terhadap rekreasi atau wistaa di Pantai Jumiang yang terus meningkat. Pada beberapa tahun yang lalu, Pantai Jumiang mulai dilupakan oleh wisatawan lokal. Hal ini dikarenakan terbatasnya atraksi wisata yang terdapat di pantai ini. Selain itu, kondisi fasilitas wisata juga kurang mendukung. Hal ini tentu memengaruhi jumlah kunjungan wisatawan.

Masalah-masalah di atas ternyata disebabkan oleh beberapa faktor. Pertama, kurangnya sinkronisasi antara Dinas Pariwisata Kabupaten Pamekasan dan pengelola Pantai Jumiang. Kedua, kurangnya partisipasi masyarakat di sekitar Pantai Jumiang dalam upaya pengembangan wisata Pantai Jumiang. Ketiga, kurangnya minat masyarakat Kabupaten Pamekasan dalam mempromosikan Pantai Jumiang. Hal ini disebabkan karena kondisi Pantai Jumiang yang kurang tertata dan terurus, sehingga minat kaula muda untuk mempromosikan menjadi berkurang.

Program Kuliah Kerja Nyata (KKN) Tematik yang diselenggarakan oleh Sekola Tinggi Ilmu Ekonomi (STIE) Bakti Bangsa Pamekasan ternyata mampu melirik permaslaahn yang ada di kawasan wisata ini. Dengan tema "Desa Priwisata Berbasis Kearifan Lokal" diharapkan mampu menjawab berbagai permaslaahn yang ada di kawasan wisata ini. Didukung oleh hasil kajian yang dilakukan oleh Tim Peneliti dari Dosen STIE Bakti Bangsa Pamekasan, kegiatan pengabdian ini merupakan hasil kerjasama antara program KKN dengan penelitian dosen pemula (PDP) yang diberikan dana hibah oleh Kementerian Riset, Teknologi, dan Pnedidkan Tnggi. Dengan program kolaborasi ini diharapkan agar Pemerintah Kabupaten Pamekasan dan pengelola Pantai Jumiang dapat terus mengevaluasi diri dalam melakukan pengembangan wisata lokal. Dengan demikian, tujuan untuk menjadikan Pantai Jumiang sebagai wisata edukasi yang berkelanjutan (education sustainable tourism) dapat tercapai.

\section{Metode pengabdian}

\section{Waktu dan Tempat Pengabdian}

Kegiatan pengabdian ini dilakukan di Desa Tanjung, Kecamatan Pademawu, Kabupaten Pamekasan. Lokasi pengabdian ini juga merupakan lokasi penelitian. Alasan utama pemilihan lokasi ini adalah salah satu ikon wisata unggulan di Kabupaten Pamekasan. Waktu pengabdian dilakukan selama enam bulan, yakni sejak Februari hingga Maret 2019. 


\section{Metode dan Rancangan Pengabdian}

\section{Tahapan Awal}

Awal kegiatan dalam pengabdian ini adalah melakukan wawancara kepada pengelola dan stakeholder terkait dengan kondisi keterkinian kawasan wisata Jumiang, baik kendala, hambatan, dan potensi yang dapat dimiliki untuk dikembangkan. Kegiatan wawancara menggunakan system focus grup discussion (FGD) yang telah disiapkan oleh tim peneliti. Kemudian, tim peneliti mencatat poin-poin penting mengenai hasil FGD.

Tahapan Pelaksanaan

Pelaksanaan pengabdian dilakukan dengan melakukan berbagai program pengabdian kepada kelompok sadar wisata atau dkenal dengan istilah Pok-Darwis di kawasan wisata Jumiang. Penuturan mengenai program kerja kegiatan pengabdian disampaikan melalui presentasi di depan Kepala Desa Tanjung, anggota Pok-Darwis, dan tim peneliti.

Setelah melakukan presentasi, tim peneliti, mahasiswa KKN, dan Pok-Darwis menentukan jadwal pelaksanaan pengabdian. Pelaksanaan kegiatan pengabdian ini dilakukan sesuai dengan timeline yang telah disepakati. Setiap kegiatan pengabdian akan dimonitoring dan dievaluasi, baik oleh tim peneliti maupun panitia KKN STIE Bakti Bangsa Pamekasan.

\section{Tahapan Monitoring dan Evaluasi}

Kegiatan monev dilakukan dengan melihat apakah terdapat perubahan sikap, pemikiran, dan persepsi terhadap banjir. Tahapan ini dianalisis dengan menggunakan hasil wawancara dan diolah dengan menggunakan Microsoft Excel.

\section{Pengambilan Sampel}

Objek utama dalam kegiatan pengabdian ini dalah Pok-Darwis kawasan wissata Jumiang. Kelompok masyarakat ini adalah pengelola dari kawasan wisatatersebut. Jumlah masyarakat yang terlibat dalam kegiatan pengabdian ini adalah berjumlah 18 orang. Seluruhnya merupakan anggota dan pengurus PokDarwis kawsan wisata Jumiang.

\section{HASIL DAN PEMBAHASAN}

\section{Pemasangan Papan Petunjuk}

Kegiatan ini bertujuan memberikan keterangan kepada para pengunjung yang datang ke setiap spot yang ada di kawasan wisata Jumiang. Papan ini juga bertujuan untuk menunjukkan arah menuju spot wisata. Papan terbuat dari papan kayu yang kemudia dicat dan dberi tulisan berupa arah petunjuk, nama spot wisata, atau kata-kata peringatan untuk tetap menjaga kawasan wisata agr tetap bersih dan rapih.

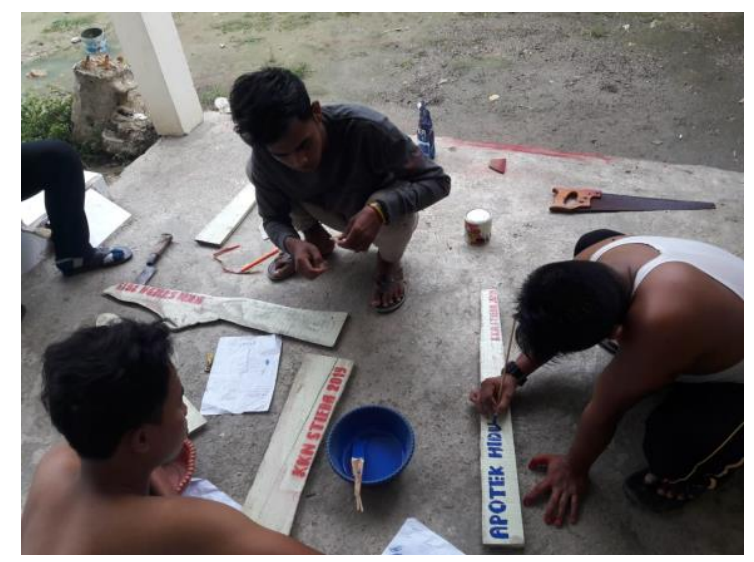

Gambar 1 Pengecatan Papan Petunjuk Pembersihan Pantai Jumiang Bersama Bupati dan Dinas Terkait 


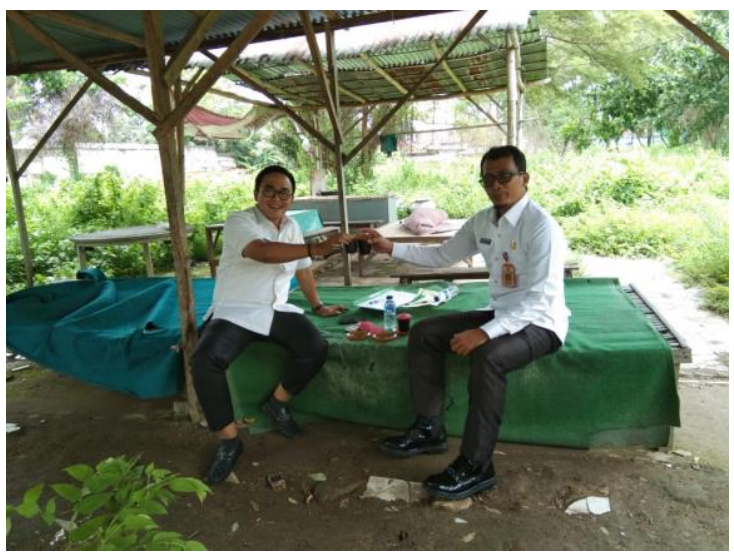

Gambar 2 Bapak Bupati dan Dinas Terkait Saat Mengikuti Kegiatan Pembersihan Pantai Jumiang

Kegiatan ini bertujuan untuk membersihkan kawasan wistaa Jumiang, baik di bagian puncak mapun di bagian pantai. Seperti kita ketahui, bahwa sampah merupakan momok terbesar bagi keberlangsungan hidup, tidak hanya bagi manusia namun juga makhluk hidup lainnya. Kawasan wisata Jumiang juga memiliki masalah pengelolaan smapah wisata yang belum tertangani dengan jelas. Kegiatan pembersihan Pantai Jumiang ini ternyata disambut baik oleh Pemerintah Daerah Kabupaten Pamekasan. Terbukti, Bapak Bupati H. Badrut Tamam dan jajarannya juga ikut serta dalam kegiatan ini.

Tidak hanya itu, kegiatan pembersihan pantai ini juga diikuti oleh berbagai elemen masyarakat. Termasuk berbagai Lembaga Swadaya Masyarakat (LSM) yang mencintai lingkungan juga ikut berpartisipasi. Hasil dari kegiatan ini adalah kawasan wisata Jumiang yang lebih bersih dan menambah kesan positif kepada para pengunjung, serta terus mempromosikan kawasan wisata Jumiang kepada masyarakat luas.

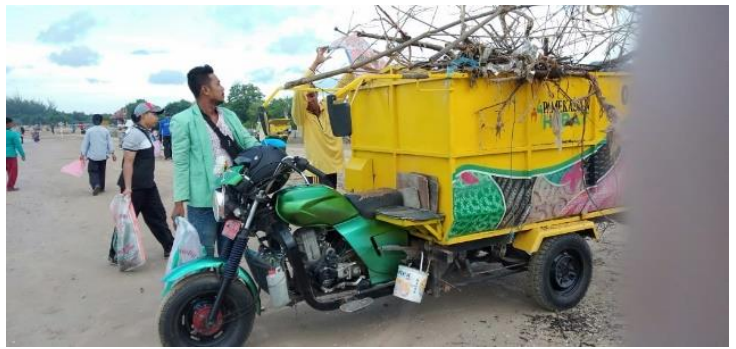

Gambar 3 Mahasiswa KKN STIE Bakti Bangsa Membersihkan Kawasan Pantai Jumiang

Pemanfaatan Sampah Wisata

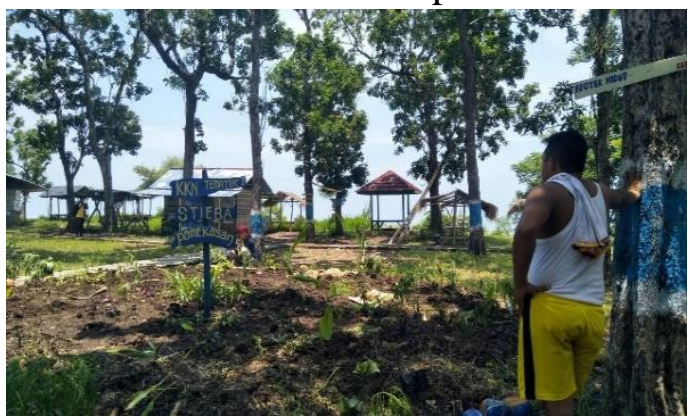

Gambar 4 Pembuatan Apotik Hidup

Sampah wisata di kawsan Jumiang adalah berupa plastick bekas kopi bubuk dan sampah batok kelapa muda. Sampah ini berasal dari stan makanan dan minuman yang berada di kawasan Jumiang di puncak. Tim peneliti dan mahasiswa KKN STIE Bakti Bangsa Pamekasan ebrsepakat untuk mendaur ulang smapah-sampah tersebut. Salah satunya adalah dimanfaatkan sebagai pot ramah lingkungan. Pot ini dicat warnawarni kemudian diisi dengan berbagai macam tanaman hias. Setelah itu, pot ramah lingkungan diletakkan mengitari pohonpohon yang ada di sekitar kawasan wisata Jumiang. Hasil dari kegiatan ini adalh mengurangi jumlah tumpukan batok kelapa yang tentunya mengganggu pemandangan sekaligus menambah efek warna-warni di sepanjang kawasan wisata.

Pembuatan Mading Sejarah Sebagai Media Edukasi

Kegiatan ini bertujuan utama untuk mengenalkan sejarah tentang makam Adirasa yang terdapat di Puncak kawasan wisata Jumiang. Mading ini terbuat dari kayu yang disertai dengan banner kecil 
berisikan sejarah singkat mengenai Adirasa. Hasil dari kegiatan ini adalah tetap terjaganya Makam Adirasa yang telah menjadi salah satu ikon dari kawasan wisata Jumiang.

Pengecatan Pohon untuk

Memperindah Pemadangan

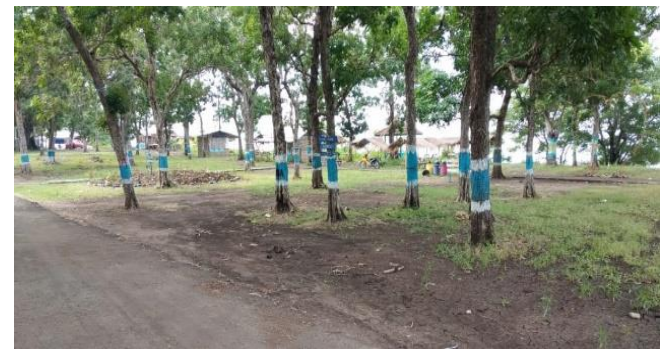

Gambar 5 Pemandangan Kawasan

Wisata Jumiang Bagian Puncak Setelah Pengecatan Pohon

Kegiatan ini bertujuan untuk menambah keindahan dari setiap pohon yang ada di kawasan wisata Jumiang. Sebagai kawasan wisata yang termasuk dalam kategori wisata alam dan wisata bahari, kawasan wisata Jumiang memiliki daya Tarik tersendiri. Ketika musim gugur tiba, dedaunan menjadi berjautuhan dan pepohonan seolah mongering. Hal ini justru menjadi spot menarik untuk berswafoto bagi kalangan anak muda. Pun demikian saat pepohonan mulai bersemi, deadunan menjad menghijau, pun tak kalah menjadi spot unik sebagai latar. Pengecatan yang dilakukan oleh mahasiswa KKN STIE Bakti Bangsa Pamekasan dirancang untuk menambah nilai estetika bagi keberadaan pepohonan di sepanjang kawasan wisata Jumiang.

Pelatihan E-Marketing Pada PokDarwis Kawasan Wisata Jumiang

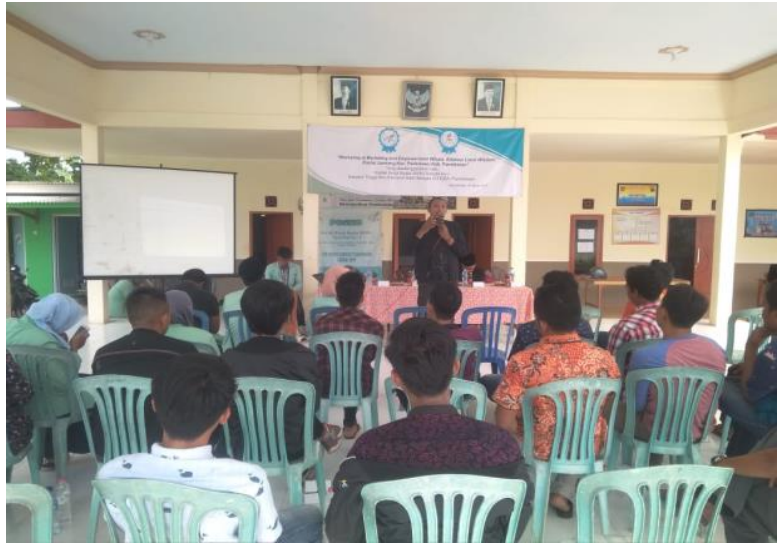

Gambar 6 Saat Workshop E-Marketing

Pok-darwis merupakan objek utama

dalam kegiatan pengabdian ini. Tidak hanya menambah keindahan kawasan wisata saja, tim peneliti juga berupaya agar kemampuan (softskill) dari anggota POkDarwis juga semakin meningkat. Pemberdayaan dan pendampingan kepada Pok-Darwis diwujudkan dengan diadakannya pelatihan dan workshop emarketing dalam upaya mempromosikan Kawasan Wisata Jumiang melalui social media. Tanggapan dari anggota PokDarwis sangat luas biasa. Terlebih, tim peneliti dan panitia KKN juga memberikan web atau blog yang dapat digunakan sebagai media untuk mempromosikan wisata Jumiang. Narasumber yang didatangkan merupakan dosen ahli d bidang Marketing Management dari STIE Bakti Bangsa Pamekasan.

Kolaborasi Pok-Darwis dan Kelompok Tani Rumput Laut Sebagai Wisata Edukasi Berbasis Kearifan Lokal

Kawasan wisata Jumiang sebenarnya memiliki dua spot utama, yakni kawasan Pantai Jumiang dan kawasan puncak. Kawasan Pantai Jumiang berupa daerah pesisir dna pantai, terdapat atraksi wisata banana boat dan penanaman rumput laut yang dilakukan oleh Kelompok Tani Rumput Laut. Sedangkan kawasan puncak merupakan kawasan dimana terdapat Makam Adirasa dan spot untuk melihat pemandangan Selat Madura dari ketinggian ribuan meter dia atas permukaan laut. 
Selama ini, penanaman rumpu laut yang dilakukan oleh Kelopok Tani Rumput Laut belum dioptimalkan sebagai atraksi wisata secara legal. Hal tersebut snagat disayangkan. Kegiatan tersebut dapat menjadi atraksi wisata yang snagat menarik. Terlebih Desa Tanjung dkenal sebagai salah saru produsen rumput laut terbaik di Pulau Madura. Kegiatan kolaborasi antara Pok-Darwis dan Kelompok Tani Rumput Laut dirasa menjadi suatu inovasi agar kawasan wisata Jumiang lebih mampu mendunia. Tujuan akhir yang ingin dicapai adalah tercapainya suatu kawasan wisata edukasi yang berkelanjutan (education sustainable tourism).

\section{Kesimpulan Dan Saran}

Kegiatan pemberdayaan PokDarwis di kawasan wisata Jumiang meberikan dampak positif dan disambut antusias. Kegiatan pengabdian ini merupakan kolaborasi anatar Tim Dosen Peneliti dan mahasiswa KKN Tematik STIE Bakti Bangsa Pamekasan. Ke depannya, semoga program KKN dapat membuat program-program yang mampu memberdayakan masyarakat yang snagat dekat dengan kampus. Setelah kegiatan pengabdian ini berakhir, semoga pihakpihak yang diberdayakan dapat terus melanjutkan semangat demi tercapainya kawasan wisata Jumiang sebagai wisata edukasi yang berkelanjutan (education sustainable tourism).

\section{Ucapan Terima Kasih}

Artikel ini merupakan bagian dari hasil kerjasama penelitian yang berjudul Analisis Kelembagaan Dan Persepsi Wisatawan Terhadap Atraksi Dan Fasilitas Wisata Di Pantai Jumiang, Pamekasan Dalam Upaya Pengembangan Wisata Lokal dengan tim KKN Tematik STIE Bakti Bangsa Pamekasan. Ucapan terimakasih disampaikan oleh penulis kepada Kementerian Riset, Teknologi, dan Pendidikan Tinggi Republik Indonesia melalui Hibah Dana Penelitian Dosen Pemula Tahun Anggaran 2019 dan tim KKN Tematik STIE Bakti Bangsa Pamekasan.

\section{DAFTAR PUSTAKA}

[BPS] Badan Pusat Statistik. 2018. Kabupaten Pamekasan Dalam Angka 2018. Tersedia pada: http://pamekasankab.bps.go.id/publicat ion/.

[BPS] Badan Pusat Statistik. 2018. Kecamatan Pademawu Dalam Angka 2018. Tersedia pada: http://pamekasankab.bps.go.id/publicat ion/.

Umam NC. 2015. Analisis Kelembagaan Dan Strategi Pengembangan Wisata Pantai Pasir PutihMalikan (Papuma) Jember, Jawa Timur [Skripsi]. Bogor (ID): Institut Pertanian Bogor.

Yoeti OA. 2010. Dasar-dasar Pengertian Hospitaliti dan Pariwisata. Bandung (ID). P.T. Alumni Bandung.

Asri N, Fadilah E, \& Basith AA. 2018. Pelatihan Pemanfaatan Media Sosial Untuk Promosi Pariwisata dan Potensi Kearifan Lokal Di Pantai Sayang Keualang Kabupaten Garut. Jurnal Pengabdian Kepada Masyarakat, (2)12. Bakti I, Sumarnitis S, Damayanti T, \& Nugaraha AR. 2018. Pelatihan Komunikasi Pariwisata Berbasis Media Sosial (Instagram) Di Kabupaten Pangandaran. Jurnal Pengabdian Kepada Masyarakat, (2)12: 1003-10 

